\title{
COMPARING CHINA AND INDIA'S DISPUTED BORDERLAND REGIONS: XINJIANG, TIBET, KASHMIR AND THE INDIAN NORTHEAST
}

\section{INTRODUCTION:}

India and China are seen as the rising giants on the Asiatic mainland today. After the East Asian miracle or miracle of the Asian Tiger economies of the mid-nineties, attention has shifted from the peripheral parts of the Asia Pacific, towards the Asiatic mainland, mainly towards India and China. Both countries have been experiencing impressive economic growth rates since they opened up their economies and exposed their domestic markets to international competition. China opened up its markets in the late seventies, and India opened up its markets in the early nineties. Before the seventies, both economies were by and large protectionist, and had a sluggish economic growth rate. Now, of course, both countries are seen as exciting economic destinations for international investors due to their adventurous markets, which western investors feel the need to tap into and exploit. India, of course, also has the additional prestige of being the world's largest democracy. However, one area that still remains quite under researched, or at least gets side-lined due to all the talk on economic growth and development is the political situation and the on-going conflicts in the borderland regions of these two emerging powers. Having an understanding of the political situation in the borderland regions is important because if the situation ever blows out of proportion, this could potentially have an adverse impact on the economy, which indirectly impacts on our lives in the west, since western governments have invested so much money in these two countries. Living in a globalised era of inter connectedness where western finance and capital is so inextricably tied up with eastern economies, one can no longer afford to ignore these problems, and see so called eastern problems as problems of the east, because of the repercussions that they may have on the West.

The PRC/People's Republic of China came into existence in 1949 after the civil war between the Communists and the Nationalists', and India gained independence from British colonial rule in the year 1947. Since both countries came into existence, the national governments of both countries have struggled with the situation in their contested borderland regions. It is the aim of this paper to look at the changing nature of the conflict in Chinese Xinjiang and Tibet, and also to look at the political situation in neighbouring Indian Kashmir and the Indian northeast. Xinjiang and Kashmir are useful case studies because both provinces are predominantly Muslim, and since $9 / 11$, the national governments of both countries have viewed these provinces unfavourably as the epicentres of radical Islam. Tibet and the Indian northeast are also comparable because they both have a strong Buddhist presence, although the Indian northeast is more diverse culturally and ethnically. Furthermore, all four regions have been used and seen as buffer zones by their respective countries. The paper traces the conflict from the early fifties onwards till the post 2000 era, and pays special attention to how these conflicts have evolved and changed their character with the passage of time. The paper also looks at the state policies which have been taken by the national governments of these two countries, to deal with these on-going conflicts. Finally, the paper compares and contrasts the situation between the two countries, and looks at areas of similarity and differences. Whilst doing the comparison, after looking at some historical background, the paper pays special attention to three selected areas or key themes which are found in all of the conflicts. These include: the role played by ethnic nationalism, the role played by the diaspora in the conflict or the impact of external connections on the conflict, and the human rights situation. The paper argues that despite the 
differences in the nature of the political systems of the two countries, (one being democratic and the other being a predominantly authoritarian state) the state policies directed towards these peripheral regions and the nature of these conflicts have been strikingly similar.

Methodologically, the paper follows a bottom-up approach and emphasises on the voices of the ordinary people. The arguments put forward by the people are often not in keeping with the stories, and arguments put forward by the political elite. In depth interviews were carried out to further the arguments in the paper. The bottom-up approach was carried out by doing semistructured or non-directive interviews with people from these conflict zones. 'The least structured form of interviewing is the non-structured or non-directive interview. Here no pre-specified set of questions is employed, nor are the questions asked in a specified order' [1]. There is no schedule. 'With little or no direction from the interviewer, respondents are encouraged to relate their experiences, to describe whatever events seem significant to them, to provide their own definitions of their situations, and to reveal their opinions and attitudes as they see fit. The interviewer has a great deal of freedom to probe various areas and to raise specific queries during the course of the interview' $[1]$. This flexibility and the spontaneity with which the interviewees respond are most certainly some of the strengths of this method.

Now let us first start with India, and then in the second half of the paper we will be looking at China.

\section{INDIAN KASHMIR: BACKGROUND TO THE CONFLICT}

Kashmir happens to be located at the cross roads of South Asia, Central Asia and China. The conflict here has essentially been a nationalist secessionist movement with strong involvement of external powers like Pakistan. 'Secession is a bid for independence through the redrawing of a state's geographical boundaries in order to exclude the territory that the seceding group occupies from the state's sovereignty'[2]. That said, the nature of the conflict has changed with the passage of time, especially in recent years. The Kashmir conflict, immediately after 1947, had a strong external dimension, but in recent times, this external dimension seems to have mellowed down, but the internal dimension of the conflict has flared up [3]. The main issue has been over selfdetermination and the achievement of political independence or at least for more autonomy from India. Kashmiri's have often seen them-selves as a distinct nation, whose cultural identity differs from that of mainstream Indians. What has complicated the situation has been Pakistani involvement in the conflict. 'The two sides i.e. India and Pakistan have sought to hold onto Kashmir out of the imperatives of statecraft and little else'[4]. Both countries have fought over Kashmir on four occasions since 1947.

In 1947, after India gained independence from British colonial rule, Kashmir as an independent princely state had the choice of acceding to either India or to Pakistan, according to the conditions of partition. For most of the then British Indian states, the choice was straight forward and clear which side to join, based on geographical proximity and demographics. For Kashmir, however, the situation was quite tricky because it was not only sandwiched in between India and Pakistan, but had a Hindu ruler, Maharaja Hari Singh, governing over a predominantly Muslim region. Pakistan has never been comfortable with Kashmir being a part of India since it is predominantly a Muslim region. 'The Pakistani elite view India as an expansionist, arrogant and bullying state that has not accepted the reality of partition and is determined to destroy or 
subjugate Pakistan' [5]. The political elite from Pakistan have often argued that Pakistan's national identity will never be complete unless it captures the whole of Kashmir which is a Muslim majority province leaning against Pakistan's borders. 'It was Zulfikar Ali Bhutto who once said that Kashmir must be liberated, if Pakistan is to have its full meaning, and Pakistani politicians share responsibility for encouraging ordinary Pakistanis to see jihad in Kashmir as legitimate' [6]. 'Pakistan's case in Kashmir is based mainly on its assertion that the majority of Kashmiris are Muslims and that therefore Kashmir must become a part of Pakistan. The premise is that the religion of a given people determines their nationality and their political affiliation'[7]. 'Pakistan's assistance of the Kashmiri separatist movement is evidently a manifestation of the belief that the predominantly Muslim state of Jammu and Kashmir should have become part of the country at Partition in 1947' [8]. Both people and politicians in Pakistan have come to 'define Pakistan as antithetical to India, the permanent other'[9]. At different points of time in history, Pakistan has tried to free Kashmir from India, especially when it perceived India as weak militarily. The first time was in 1947/48, when an internal rebellion broke out in Poonch, Kashmir against the then ruler, Hari Singh. The Pakistani side saw the rebellion as signs of tremendous dissatisfaction amongst a Muslim community who were finding Hindu rule in the region increasingly oppressive. Thus to help the rebels, Pakistan had sent in her troops. It was at this point when Singh asked for Indian assistance from the then Indian leader, Nehru. India, under Nehru agreed to help on the condition that Kashmir would have to accede to the Indian side. A document called the Instrument of Accession was signed between the two parties, and the rebels were finally crushed by the Indian army. The Instrument of Accession was signed on the understanding that there would be a plebiscite, which never really took place. 'The plebiscite promised by India, agreed to by Pakistan and reiterated by the United Nations, to enable the people to resolve J\&K's international status, has never been held. Nor is it likely to be held'[10]. After this, it was agreed between Kashmir and India, that India would have control over Kashmir only in three areas and three areas alone which included: defence, external relations and communications[11]. Kashmir was to have special status, unlike the other Indian states. For instance, the Kashmir flag was to fly alongside the Indian flag. However, with the passage of time, we see how the so called special status of Kashmir gets eroded by India's policy of high handedness in the region. For instance, the Indian government started to exercise emergency powers in the region which was not to be the case without the prior approval of the regional government of Kashmir. Furthermore, we also see how the post of the sadr i riyasat, which was a political position specific to Kashmir, gets abolished. The sadr i riyasat was turned into the governor and the prime minister of Kashmir becomes the chief minister, like all the other Indian states. These were clear signs to the people of Kashmir that the special status of Kashmir was not being respected and that India was gradually tightening its grip over Kashmir. As India started to tighten its grip over the Kashmir region, one man who was continuously proving to be problematic was Sheikh Abdullah and his party, the National Conference Party. The Indian government realised later that it would be difficult to crush him and his party all together, so an alliance came into existence in the later decades, called the Conference-Congress Alliance. This alliance won the elections in the eighties, but amidst a lot of political violence. Local people believed that the elections had been rigged, and when protests broke out, India responded with repression, physical torture and harassment and intimidation of the voters. The use of unproductive force from the Indian side from time to time has only exacerbated the situation.

As India had started to tighten its grip over Kashmir, this unsettled Pakistan, and a 'now or never' mentality dominated the mind-set of the Pakistani military generals in the mid-sixties. 
Pakistan thus made an attempt to capture Kashmir in 1965, thinking that India was weak from a military standpoint since it had just been defeated by China in the border conflict of 1962, so they came to the conclusion that this was a good time to attack India, and free Kashmir. This plan however did not work. Pakistani dictator General Ayub Khan's grand design of snatching Kashmir failed miserably in the 1965 war[12]. India proved to be too strong for Pakistan and an agreement was finally signed in Tashkent in 1966, which was supervised by the former Soviet Union that brought the whole episode to a close.

The war which took place in 1971 strongly ties in with the Bangladesh nationalist movement, although it had huge implications for the situation in Kashmir. Indian involvement in this war was very strong. In fact the Bengali nationalists could only succeed because of the help they got from India. As the rising tide of Bengali nationalism started to gain in strength in the late sixties, and early seventies, Pakistan found it increasingly difficult to hold the two Pakistan's together. When Pakistan was created in 1947, it consisted of a West Pakistan, which is today's Pakistan and what was called East Pakistan or present day Bangladesh. The two Pakistan's had a very uneasy existence with thousands of miles of Indian territory in between, which separated the two Pakistan's. The situation was like this from 1947 till 1971. It was in the year 1971, when former East Pakistan seceded from West Pakistan/Pakistan. Throughout this period, the Bengali people of former East Pakistan were feeling very oppressed by west Pakistani rule. 'They had become part of Pakistan by giving primacy to their Muslim identity, but culturally they were very different from the people of what came to be known as West Pakistan'[13]. For instance, they spoke Bengali, and not Urdu. They felt underrepresented in political, economic and military circles, and that their culture was also being disrespected openly by west Pakistani politicians. 'Bengalis formed just over $50 \%$ of the population in undivided Pakistan, but were poorly represented in the two main non-elected institutions of the state: the military and civil bureaucracy'[14]. In all the previous Kashmir wars India had to fight on two fronts. If India helped the Bengali nationalists like the Awami League Party to gain independence, then in future wars, it would not have to fight with Pakistan over Kashmir on two fronts. Thus, India helped the Bengali nationalists, and the independent country of Bangladesh came into existence in 1971, after the liberation war. The strategic thinkers at New Delhi now felt a sense of relief since they would not have to fight against Pakistan on the eastern front if they went to war with Pakistan over Kashmir in the post 1971 period. In other words, Indian strategic thinkers could now solely concentrate their men and resources on the western front.

In the late nineties the fourth Indo Pak or fourth Kashmir war broke out due to Pakistani infiltration across the Line of Control, which is the demarcating line between Indian Kashmir and Pakistan occupied Kashmir. Although there was a lot of fear that the situation would pave the way for a conventional war to take place and even a nuclear conflict, 'a conventional but localised war ensued'[15]. Battles were fought at Kargil, Dras and Batalik. This war is often called the Kargil War of 1999. It has been argued that 'in Jammu and Kashmir, after the operations in Kargil in 1999, the state witnessed a sharp increase in Pakistan assisted infiltration of trained Islamist terrorists from across the Line of Control'[16].

On-going and protracted conflicts around the world are never static, but are subject to constant change. They change their identity and colour from time to time. These conflicts are all multi-faceted, and each facet seems to gain prominence at a particular point of time in history. 'What began as a territorial dispute over a princely state that borders India and Pakistan, has 
evolved into a highly politicised conflict that has taken on multiple dimensions'[17]. When we look at the current situation in Kashmir, the external dimension, or Pakistan's direct involvement in the conflict seems to have mellowed down to a large extent, although it is worth mentioning that locals still believe that there is on-going infiltration from the Pakistani side. But the conflict seems to have gotten worse due to India's policy of high handedness in the region, and the stationing of security personnel to supposedly 'manage' the conflict. Kashmir has been classified as a disturbed area by the Indian political establishment at New Delhi. Because of this label, the Armed Forces Special Powers Act/AFSPA has been applied to the region. This is an act which gives security personnel stationed in the region, enormous powers to deal with the situation. The region is heavily militarised and the security personnel often abuse and misuse the Armed Forces Special Powers Act, which has paved the way for all sorts of human rights violations to take place. 'International human rights organisations, as well as several Indian civil rights groups, have documented in detail the atrocities committed on the people of Kashmir by both Indian security forces and militant groups'[18]. The Indian security forces stationed in the region who are supposedly managing the conflict include the BSF/Border Security Force, the CRPF/Central Reserve Police Force and the RR/Rashtriya Rifles. The security personnel, who tend to come from India proper, do not show much respect for the local people, for local religious cultural sentiments, and there is no accountability. They have misused the AFSPA on numerous occasions, and shot people based on mere suspicion. Raping of women, desecration of mosques/religious buildings, physical torture, and verbal abuse seems to be the order of the day since there is no accountability. In other words, those who are supposed to be the keepers of law and order in Indian Kashmir are in actual fact the creators of political turmoil and mayhem. The Kashmir conflict is most certainly one of the most complex conflicts in the world today and is multi-dimensional in nature, but it is this facet of the conflict which analysts currently need to pay special attention to. Those who are supposed to maintain peace and stability are the ones who are causing problems in the region on a day to day basis.

I got the opportunity to carry out a one hour interview with a Muslim man from Kashmir. When I asked him about the situation in Kashmir and how it had changed with the passage of time, from the fifties till more recent times, this is what he had to say. The Indian security forces or jawan's as they are called are basically frustrated individuals. They have nothing to do and hence to keep themselves entertained and busy, they pick on the local people[19]. These jawan's are not exactly senior officers and hence they lack very basic intelligence and education. They intimidate local Kashmiri people and subject them to all kinds of abuse: physical and verbal. This has often led to violent clashes between the local Kashmiri's and the Indian security forces stationed in the region. Kashmiri's do not exactly feel 'Indian' or a sense of one-ness with India proper [19]. If Kashmiri's say that they are 'Indian', and want to be a part of India, this is primarily because of economic reasons. To some extent Kashmir is dependent on India for its survival. One cannot force a sense of Indianness to grow amongst Kashmiri's. In other words, one cannot force a sense of loyalty to grow amongst Kashmiri's towards India especially if India treats Kashmiri people so badly. If feelings of loyalty towards India have to grow, they will grow naturally with time-it cannot be forced by New Delhi and certainly not by the Indian Army and other para military forces. Kashmiri's do not exactly grow up hearing the Indian national anthem which is jana-gana-mana. And as for flag hoisting, it happens only in official buildings that deal with administration in places like Srinagar, which is the capital of Indian Kashmir[19]. 
The same man also spoke about the racial discrimination which Kashmiri's are subjected to in India proper, especially when young Kashmiri men travel to India proper for purposes of education and employment. He also spoke about the Kashmiri pundits who he thought were educated, but very corrupt. Because of the entrenched corruption amongst the Kashmiri pundits, who were from a predominantly Hindu background, the local Kashmiri's felt the need to attack them on a few occasions, and so they did. The pundits then informed the Indian Army, and mentioned that these attackers were militants. Later on the armed forces would come and harass the so called 'militants'[19].

Because of the strained relations between the Indian armed forces and the Kashmiri locals, some of these locals would actually cross over to neighbouring Pakistan to train, in order to fight back, against the oppression of the Indian army. Many of these Kashmiri men were brainwashed, and this obviously added to the problem. After the training from Pakistan, many would come back to the Indian side with guns or at least would have access to guns, which mainly came from Pakistan[19]. These Kashmiri men who had access to guns tried to harass other local people, and tried to make money from the on-going violence. Many would start demanding money from other locals. The locals would often feel scared seeing the weapons, and would surrender what they had [19]. This was precisely the time in India's contemporary history when the Kashmir cause lost popular support because the local people were being harassed and intimidated by other Kashmiri men who had access to guns and were trying to make money out of the political situation. Men with guns would grab fruits and vegetables from local fruit sellers and harassed these fruit sellers with their guns. The same men would also go from door to door with receipt books, demanding money from the local people[19]. This situation happened from the late eighties and early nineties onwards.

External infiltration would take place from the AF-PAK/Afghanistan-Pakistan region and these external militants would attack the Indian Army stationed in the area. This was when the local people of Kashmir actually thought that Pakistan was in favour of them and was actually trying to help them and free them from Indian oppression. When Kashmiri locals were attacking other locals, this is when the Pakistani establishment realised that the situation had gone out of control, and when it had to directly intervene. Its intervention took the shape of attacks on the Indian Army. My interviewee also mentioned that Pakistan has always wanted to meddle in Indian affairs, and even went to the extent of offering money and proper salaries to Kashmiri families if they would carry out the plans directed by the Pakistani military establishment[19]. This was mainly to attack Indian security personnel.

My interviewee also went onto say that the whole issue was very much politicised[19]. If the Indian National Congress Party gave up Kashmir, then the opposition party would spend the next decade or two hurling accusations at the Congress for breaking up the country. He ended the interview by saying that most Kashmiri's are so poor that they cannot leave the state of Kashmir, so their image of India is the picture and image which they get from the Indian security forces who tend to come from India proper[19]. This image which the Indian forces give the people of Kashmir is quite a dark and gloomy image. They are known to be hostile and cruel. According to the Kashmiri people, the Indian Army and other para military forces are seen as the representatives of the Indian state, and hence the people tend to generalise, and begin to think that people in other parts of India are also like the Indian armed forces. My interviewee's final note was that despite the years of 
turmoil, the situation now is a lot calmer, and the people have almost given up the fight against India.

Now that we have dealt with the situation in Kashmir, let us turn to the conflict in the Indian northeast.

\section{THE INDIAN NORTHEAST: BACKGROUND TO THE CONFLICT}

The Indian north east consists of the seven sister states which include Assam, Manipur, Nagaland, Arunachal Pradesh, Tripura, Meghalaya and Mizoram. The region encompasses $7.6 \%$ of the land area, and has $3.6 \%$ of the country's population[20]. Out of all the states, Assam has a dominant and central position in the region. In fact many of the other states were carved out of Assam to resolve the tension between different ethnic groups and tribes[21]. 'The region is an ethnic minefield, as it comprises around 160 Scheduled Tribes'[22]. The Indian north east is often called the mongoloid fringe of India. Because of the historical phases of migration which have taken place from different parts of East Asia to this part of India, the people of the Indian north east are often confused for being Chinese or East Asian as opposed to being South Asian. 'Many communities in North East India trace their origin to Southeast Asia'[23] This region like Kashmir also experiences a difficult mountainous terrain. The region suffers from geographical isolation and much of the political violence in the region originates from strong feelings of isolation and alienation. The region is connected to the rest of India with a small strip of land called the 'Chicken's Neck'.

The region has always experienced complicated relations with the rest of India, and the conflict here exists at many different levels. The first level of conflict is of course between the region as a whole and with the rest of India or more correctly with New Delhi. The north eastern states have argued that New Delhi has not paid sufficient attention to the on-going problems of the north east. However, there are also other levels of conflict. The region is predominantly a tribal region, and so there are conflicts between different tribal groups. There are conflicts between tribals and non tribals. There are also conflicts between different states in the region. The region itself is highly fragmented along racial, religious, linguistic and tribal lines. It should be noted that in ethnically sensitive societies, problems associated with ethnic tension may develop intentionally or unintentionally[24]. 'By the turn of the 1990's, India's North eastern region witnessed a proliferation of ethnic groups vying for different levels of autonomy, ranging from claims for autonomous district councils to redrawing of state boundaries to create new states'[25]. There are also huge differences between the people who see themselves as sons of the soil or insiders, and those who are perceived as outsiders. External powers such as China and neighbouring Burma have been actively involved in the region's conflict. 'The affinity of groups with their kin groups across the border and the sense of support (both material and non-material) they derive from them, have had serious implications'[26]. Other countries, which have been involved in the region, include Nepal and Bhutan. However, in recent times, like the Kashmir problem, the internal side of the conflict has flared up. India's attempts at trying to assimilate the entire north eastern region have caused great concern amongst the people living there[27]. Well known American academic of Indian descent, who has spent much of his life working on the Indian northeast, Sanjib Baruah writes, 'unresolved tensions between 
regional patriotism and pan-Indianism explain the insurgent organisation's resilience and the continuing appeal of its political ideology'[28] 'The region's history as part of independent India has been dominated by political and social movements against the Indian state and against threats to ethnic identity from migrants and neighbouring communities'[29]. Also, when one travels to the region, one is immediately surprised to see how heavily militarised the region is[30]. The entire Northeast region is dotted and marked by checkpoints and troops who are constantly patrolling markets, train stations and major events[31].

The main issue here revolves primarily around self-determination and sovereignty. That said, the conflict today has almost acquired a totally different identity. States like Nagaland have struggled to gain independence from India. The Naga community feels like a distinct ethnic group which shares nothing in common with the Indian mainstream[32]. Many of the leaders of the proindependence groups in Nagaland have argued that Naga people are not Indian by choice, but by force, and were forcefully integrated into the Indian mainstream by British conquests. Now that the British have left, they should win back or regain their independence. The Naga conflict is one of the oldest conflicts in India[33]. One of the main groups which have been actively involved in the proindependence movement is the NSCN or the Naga Socialist Council of Nagaland. This is a Marxist Christian revolutionary force. 'Nagaland for Christ', has been one of the slogans of one of the factional groups of the NSCN[34]. Many of these insurgent groups have followed the political ideology of 'Nagalim' or the attempt to create what many Naga people see as a 'greater Nagaland'. The idea is to get all the people of Naga origin together into one administrative political unit. This includes Naga people from neighbouring Indian states like Manipur and Assam, and also people of Naga origin from across the international border, from countries like Burma. Because of this political ideology of bringing all Naga people together under one umbrella, Nagaland and many of its political groups have often come into conflict with neighbouring states like Manipur since Naga's have laid irredentist claims on Manipuri land. For instance, if one travels from Imphal, which is the capital city of Manipur, up north towards a place called Ukhrul, one immediately gets the impression that one is in the state of Nagaland (and not Manipur, although Ukhrul is very much a part of Manipur) because of the traditional Naga style huts in the area. Ukhrul has almost been colonised by the people of Nagaland. In other words, the lifestyle of the people in Ukhrul (which is actually in the state of Manipur) is distinctly Naga and not Manipuri[35]. Experienced analyst on Indian security, Singh writes, 'the Naga insurgency has spilled over to the neighbouring Naga inhabited Ukhrul, Senapati, and Tamenglong districts of Manipur'[36]. 'Today, more than half a century on, Manipur has over forty militant groups with varying objectives, including secession'[37]. Despite the gloomy picture, it should be noted that the situation in these troubled areas have got better to some extent especially in recent times. For instance, 'the Naga struggle has gone from a fierce war against occupational forces of India to the Naga political problem'[38].

Not only have separatist tendencies been strong in the Indian northeast, but there has also been the issue of unregulated migration mainly from neighbouring countries like Bangladesh. Security analyst based at the IDSA, New Delhi, Sreeradha Dutta writes, 'the unchecked migration often becomes the prime reason for the woes of the region'[39]. The original inhabitants of the Northeast have always debated what the status of migrants or new arrivals should be in states like Assam. The migration problem has further complicated the situation in the Indian northeast. Many tribal groups in the region have complained that their mongoloid ethos is increasingly being weakened due to the increasing waves of migration mainly from Bangladesh which has paved the 
way for a Bengali preponderance in the region. The equivalent of the Naga NSCN in Assam is a group called the ULFA/United Liberation Front of Assam. Most of these militant groups came into existence in the late seventies and early eighties of the 20th century. They tend to be quite socialistic in their approach and believe in violence to achieve their political ends. It should be noted though that many of these insurgent groups are not unified. There exist internal problems between leaders.

Factionalism and fighting between different factional groups is still very much the case today. Other factors which have added more fuel to the North eastern fire in India include poverty, unemployment, and corruption amongst the political elite, poor governance, political agitation and administrative failure[40]. Many of these factors are also inter-related, and overlap with each other. For instance, the waves of migration from Bangladesh has put tremendous strain and pressure on regional resources, and has thus invariably exacerbated economic deprivation, unemployment and the poverty problem. 'The Northeast, therefore, is in the grip of a vicious cycle of low investment and low economic opportunities, which in turn breeds ethnic divide and dissatisfaction, disillusionment, and unrest, leading to insurgency, which again drives out investment' [41]. Like Kashmir, the Indian northeast has also been labelled as a 'disturbed area' by the New Delhi political elite, and hence the AFSPA/Armed Forces Special Powers Act, also applies to this region especially to states like Assam, Manipur and Nagaland, where levels of violence are still very high. Due to it being a 'disturbed area', the region is heavily militarised. 'In such areas, the armed forces, including para military forces are given extraordinary powers'[42]. Because of the heavy presence of the Indian Army and other para military forces like the Assam Rifles, the Border Security Force and the Central Reserve Police Force, human rights violations is an everyday occurrence in the area. 'The AFSPA is an unconstitutional law, but the dubious part of this Act is the legal protection it grants to perpetrators, thereby liberating their conscience in the name of duty and service to the nation'[43].

Now that we have looked at some of the background of these conflicts in India, let us deal with some of the common themes, which apply to both.

\section{NATIONALISM AND HUMAN RIGHTS IN KASHMIR, AND THE IMPACT OF EXTERNAL FORCES:}

\section{Nationalism in the Kashmir Conflict:}

When we look at nationalism in Kashmir we need to recognise three different strands of nationalism that have given rise to the conflict situation and that these three different types of nationalism are often in conflict or at odds with each other. The first and most obvious strand of nationalism that can be easily identified within the region is the separatist nationalism amongst certain groups of Kashmiri Muslims who want a free Kashmir, separate from the Indian state. This strand of nationalism often ties in with Islamist nationalism, since many of the pioneers who are spearheading this secessionist movement are Islamist ideologues themselves. The second strand of nationalism involved in the conflict is Pakistani irredentism and is therefore seen as an external force impacting on the situation. As mentioned earlier, Pakistan would not be complete without incorporating Kashmir, which was a predominantly Muslim territory leaning against its frontier. The third strand of nationalism involved in the conflict is Hindu nationalism and the conflict in Kashmir could be seen as a response to Hindu revivalism and as a reaction against Hindu nationalism. Thus, when one looks at the role of ethno-religious nationalism in Kashmir one really needs to pay close attention to the intersection of these three types of nationalisms[44].

\section{The Human Rights Situation in Kashmir:}

When faced with armed separatism, Indian authorities have resorted to an excessive and unproductive use of force that has led to further violence by secessionists, thereby increasing the 
prospect of the disintegration of the state. In particular, the use of relatively undisciplined paramilitary forces has increased the levels of violence between the state and the separatist groups especially in Punjab and Kashmir[45]. 'The increasing use of armed force by the state has led to a corresponding erosion of democratic processes in India'[45]. As violence escalated in the eighties, the constitution was amended and special legislation had been introduced which gave the central government greater power to use force to suppress insurgency and terrorism by separatist groups [45]. Raju Thomas argues, 'the frequent use of military and paramilitary forces to suppress secessionists tends to politicise those forces and thereby increases the threat of a military takeover'[45]. On the eighth of September, 1993, the United States expressed concern over the human rights situation in Kashmir and catalogued the excesses committed by the security forces against the civilians[46]. The European Parliament also expressed concern and had its delegation denied entry into Kashmir. Basic human rights, civil liberties, legal norms and civilised values have been grossly violated by the security forces and the administrative authorities in dealing with the situation on many occasions. 'Many human rights' teams and independent groups visited Kashmir after April, 1990, thus breaking the conspiracy of silence on the issue of human rights violations'[46].

The Asia watch/human rights watch group reported in 2010[47].

'The Armed Forces Special Powers Act or AFSPA grants the military wide powers to arrest without warrant, shoot to kill, and destroy property in so called, 'disturbed areas'. It also protects military personnel responsible for serious crimes from prosecution; creating a pervasive culture of impunity...state authorities have reportedly placed several parts of the valley under curfew to contain the protests. Demonstrators have thrown stones at the security personnel and destroyed public and private property. To contain the rioters, the police have sometimes used excessive force, causing deaths and injuries with live bullets, rubber bullets and tear gas canisters. Each death has led to a fresh round of demonstrations and further violence.'

\section{Transnational Connections and the Kashmir Conflict:}

It has already been discussed that this particular conflict has a well-defined external dimension to it and that Pakistan is one of the key external actors. Indian security specialist Kanti Bajpai argues,'The Pakistan Army's ISI, Inter-Service Intelligence has provided haven, money, training, and arms to Kashmiri and other militant groups operating in the state'[48]. 'Resentment against India is rooted in Pakistan's foreign policy goals. The immediate post partition problems, including Kashmir, are not the only causes. Pakistan has been a state in search of national identity and it seeks reinforcement of its presence in the Indian subcontinent by challenging India's position as the dominant power'[49]. A major external security concern for India since the nineties is the potential of greater interaction between Pakistan and other Muslim countries in central and west Asia, and to what extent can this cooperation be used to destabilise India, through the Kashmir issue or otherwise. 'Pakistan is seeking new alliances and economic ties with the newly emerged central Asian republics'[50]. The loss of the United States of America as an ally since the end of the Cold War prompted Pakistan to step up its efforts in promoting Islamic unity in other parts of the Islamic belt, especially central and west Asia. In 1991, prime minister Nawaz Sharif, called for the creation of an Islamic Common Market. All these efforts by Pakistan carried the dual purpose of not only promoting Islamic solidarity but also confronting a much larger Hindu dominated India. In relation to transnational connections, mention also must be made of the Kashmiri diaspora and their contributions to the ongoing conflict. The Kashmiri diaspora in Britain, for instance, participates actively in the Kashmir separatist movement. 'The British Kashmiri diaspora have played the most important role in Azad Kashmiri politics at home and abroad'[51]. The Jammu and Kashmir Liberation Front was founded in Birmingham in the United Kingdom in the year 1977 with Amanullah Khan as its chair person. It is the most important manifestation of diasporic mobilisation around the situation in Kashmir. Recent research done and carried out amongst the British Kashmiri diaspora shows very clearly that Kashmiri identity is still very much bound and inextricably tied up with the territory of Kashmir and this is likely 
to remain strong as long the territory is disputed[51]. The activity of the leading members of the Jammu and Kashmir Liberation Front include: organisation of events within the diaspora, development of strategy in the west, lobbying of national and international politicians and organisation of sympathetic influential groupings in mainstream political arenas, meetings at all levels from local to international and close liaison with the Jammu and Kashmir Liberation Front in southern Asia.

\section{NATIONALISM AND HUMAN RIGHTS IN THE INDIAN NORTHEAST, AND THE IMPACT OF EXTERNAL FORCES:}

\section{Nationalism in the Indian Northeast:}

The first and most obvious characteristic feature of this conflict is separatist ethno nationalism. The major groups in the region that have had a strong nationalist/separatist agenda and have fought for independence include the United Liberation Front of Assam [ULFA], the Dima Halam Daogah in Assam [DHD], the United National Liberation Front in Manipur [UNLF] and finally the Nationalist Socialist Council of Nagaland [NSCN] led by Thuingaleng Muivah and Isak Chisi Swu. Insurgency in this part of India started with the Naga's whose movement can be traced back to 1918 with the formation of the Naga Club. In the year, 1946, the Naga National Council [NNC] was formed and it declared independence in 1947. The movement turned violent in the fifties and is still active under the leadership of the NSCN. In Manipur, two very prominent separatist armed groups include the Revolutionary People's Front [RPF] and its armed wing, the People's Liberation Army [PLA, not to be confused with the Chinese PLA]. Both these two groups have been involved in armed struggle since the seventies. They have the aim of bringing into existence a classless society in Manipur. The radical turn in Assamese nationalism may be traced back to the influx of illegal migrants from former East Pakistan, present day Bangladesh. There were also violent protests when the central government decided to remove crude oil from Assam to the heartland region, into Bihar. This was seen not only as exploitative but the regions needs being made subservient to that of India proper. The ULFA's vice chariman, Pradeep Gogoi once stated stated that the aim of his party was to create a sovereign and socialist Assam, in which 'all indigenous people may stay and all others must leave.' In other words, many of these insurgent groups in the north east see themselves as a distinct nation, separate from India proper.

\section{The Human Rights Situation:}

The human rights situation in this part of India is very bluntly put, appalling. The BSF or the Border Security Forces and the CRPF or the Central Reserve Police Force which have been stationed in the region has been causing absolute mayhem in the region, thereby escalating levels of violence. One of key groups trying to bring about peace in the region, is the Manipur Women Gun Survivors Network, who have been doing outstanding work to try and resolve the on-going conflict. The Manipur Women Gun Survivors Network website in an article published on the twelfth of March, 2012, 'Gender and Armed Conflict in Manipur' reports on how human rights are constantly abused in the region[52].

'Over twenty thousand people have been killed in the last five decades in Manipur. Today more than thirty armed groups operate in Manipur, ranging from small outfits to organisations with several thousand members. Besides them, dozens of battalions of the Indian army and several units of Indian paramilitary forces are stationed throughout the state of Manipur at the Indo Burmese border. Manipur is one of the most conflict ridden states in India. Women and children of Manipur suffer the most in the conflict even when they are not targeted directly. They are traumatised by the deaths of family members. They bear the brunt of the emotional and socio economic impact of violence. Apart from that, women themselves are particularly vulnerable to violence and intimidation 
at gunpoint is often used as a deliberate military and political tactic. Also, women and girls continue to be tortured, raped and killed at gunpoint.'

Amnesty International has also made it very clear that the excessive use of force in Manipur should be investigated[53]. Additional paramilitary have been deployed in the state and it is known that the region has been subjected to indefinite curfews. Amnesty International is concerned that troops have been ordered to 'shoot at sight' anybody defying the curfew[53]. The CRPF or the Central Reserve Police Force have been reported to have fired indiscriminately and without even warning protestors who included women, children and the elderly.

Since the situation in relation to human rights abuse and the use of force by security personnel has become so bad in the Indian north east and other borderland regions of India, an organisation that is trying to bring about change is the 'Control Arms Foundation of India', CAFI[54]. The secretary general of this foundation is writer and activist from Manipur, Binalakshmi Nepram. The aim of this foundation is to address issues relating to the use of force, proliferation of small arms and light weapons as they effect civil society particularly women, children and the elderly as also to create a movement in the subcontinent where defence and security issues are discussed through informed debate[54]. 'The Control Arms Foundation of India proposes new ideas for security thinking and works to bring together security, disarmament and development so that all forms of security national, regional and global are recognised as true manifestations of human security. Putting people first in our debates on disarmament and security is the fundamental approach of the CAFI. The key goal of this group is to organise and deliver effective research, advocacy and assist campaigners to change the attitudes, policies or practices of the government and other decision makers '[54].

\section{Transnational Connections and the Indian North East:}

It is believed by security officials in India that the conflict in this region has reached dangerous proportions because of external connections and because these external influences have impacted profoundly on the region. For instance, the Revolutionary People's Front, which is a significant armed separatist group and its armed wing, the People's Liberation Army were supposedly trained by the Chinese in the sixties and seventies in Maoist guerrilla warfare[55]. 'Most of the insurgent groups in the Indian north east have thrived primarily due to strong external influences. Countries like China, Pakistan and later on Bangladesh, have supported most of these outfits in their fight against India by making available arms, training and most importantly base areas for underground camps. The UNLF, United National Liberation Front in Manipur, the ULFA, United Liberation Front of Assam and the NSCN, Nationalist Socialist Council of Nagaland/Nagalim, procure small arms through Bangladesh's Cox bazar area. Indian intelligence sources indicate that the ULFA, United Liberation Front of Assam, has benefitted the most, with camps in Halughat (near the Bangladesh-Meghalaya border), Dhaka etc. The outfit runs around ten bases in the Mymensingh region of Bangladesh with four bases, run by the UNLF, United National Liberation Front[55]. Indian security expert, Kanti Bajpai talks about 'Bad Neighbourhoods' in relation to the influence of external powers in India's contested borderland regions[56]. 'Virtually all of the rebellions in the borderland states have been helped along by neighbouring countries. Pakistan and China have been particularly active here. Burma and Bangladesh have been less involved but, from time to time, they also have supported secessionist groups in the north east'[56]. In addition, separatist groups in Burma have joined hands with Indian separatist groups, particularly those with whom they share a common ethnic background. Pakistani intelligence agencies have used Bangladesh to maintain contacts with Indian separatists and other disgruntled groups in the north eastern parts of India. This could be partly because India has been involved in the creation of Bangladesh when it seceded from Pakistan. India has also been active in the Sindh province of Pakistan and also joined hands with the United States of America when it interfered in Tibet in the sixties. Even the Burmese have hurled accusations at the Indian government for being involved in Burmese ethnic problems and meddling in Burmese domestic affairs. India played a major role in Bangladeshi politics, by harbouring Chakma rebels, much to the chagrin and 
resentment of the establishment at Dhaka. Levels of foreign interference have differed from place to place within the north eastern region. For instance, foreign interference has been greatest in Nagaland and Manipur and much less in places like Assam and Tripura. In Assam, the United Liberation Front of Assam, ULFA, has been helped by both Burma and Bangladesh. ULFA cadres have been trained by Pakistani intelligence, apparently in Bangladesh[56]. Indeed the top leadership of the ULFA was based in Bangladesh until the latter part of 1992. ULFA members have also used areas in Burma for purposes relating to separatist activity.

Now that we have dealt with the India side of the paper, let us turn to the China side of the article.

\section{THE XINJIANG UYGHUR AUTONOMOUS REGION: BACKGROUND TO THE CONFLICT}

Geographically, Xinjiang or the Xinjiang Uyghur Autonomous Region is located in China's far North West. It shares a massive international border with the countries of Central Asia, and internally, within China it has a border with Gansu, Qinghai and the Tibetan Autonomous Region. 'It stretches some 3,220 miles from east to west and 2,660 miles from north to south, has an area of over 1,600, 000 square kilometres, almost three times the size of France, and is by far the largest administrative unit within the PRC'[57]. Like the above two Indian case studies, this region also suffers from geographical isolation. The region is often classified as a part of inner Asia, and is inhabited mainly by an ethnic group called the Uyghur's who tend to be Muslim. In addition to the Uyghur's, there are also Uzbeks, Tajiks, Kazakhs, and other ethnic groups from Central Asia. Because of the geographical isolation, they are not only cut off from the rest of China, but also from the rest of the Muslim world. 'Even though modern transportation and communication networks have narrowed the distance considerably, Xinjiang remains remote in the popular Chinese imagination' [58]. The region is rich in resources and the topography is mountainous. One reason why the region is of tremendous importance to China is because it gives the Chinese mainland access to the enormous gas and oil resources in the Caspian area of Central Asia, which it needs for developmental reasons[59]. Thus it is essential for China to hold onto Xinjiang.

The conflict in Xinjiang, like Kashmir revolves around self-determination, and the attempt made by some separatist Uyghur's to break away from China proper. The Uyghur's like Kashmiri's see themselves as a distinct nation, whose values and way of life differs hugely from that of the racial majority in China, that is, the Han Chinese. The Uyghur's are deeply religious who feel very strongly about their Islamic identity, and do not want to be a part of China proper which is officially an atheistic state[60]. When one looks at the conflict in Xinjiang, or for that matter even in places like Tibet, one really needs to look at the clash between religious identity of the local people and the Chinese state's policy of high handedness in the region[61]. Religious groups in China have historically been involved with secret societies who have tried to undermine and overthrow state power, and hence they are viewed with suspicion by the state. Uyghur's, in particular are seen to have a separatist agenda. The name of the separatist/nationalist movement is often called the ETIM/East Turkestan Islamic Movement, which is fighting for an independent East Turkestan or a Uyghur-istan. Although there is a general tendency amongst scholars to treat Xinjiang as a single homogeneous entity, expressions of Uyghur nationalism vary greatly by social group and by location in Xinjiang[62]. It is worth noting that after the collapse of the former Soviet Union in the late eighties/ early nineties, and with the creation of the independent 5 'stan's' in Central Asia [Kazakhstan, Kyrgyzstan, Tajikistan, Turkmenistan, and Uzbekistan], this incident strengthened the hope amongst some Uyghur's to dream again for an independent East Turkestan[63]. The Uyghur 
diaspora has been very active when it comes to Xinjiang's separatist politics. This is similar to the Kashmiri diaspora, especially British Kashmiri's, who are also active in liberation politics.

Since the creation of the PRC in 1949, particularly during the times of radical Maoism, like the anti-Rightist campaign, the Great Leap Forward, and the Cultural Revolution, Uyghur Muslims came under tremendous political pressure. The state viewed anything religious as backward and thus to push the process of modernisation forward, the state seized the land, and property of religious groups, and forcefully put them to secular use. For instance, mosques or for that matter monasteries in Tibet were converted into army barracks, administrative offices, granaries, factories etc. Needless to say, there was strong resistance from below. What the Chinese state saw as 'development', was not seen as development by many Uyghur separatists. Religious professionals were appointed by the state to keep a watchful eye on what was happening especially in the rural country side. Even in more recent times, 'Public safety and national security agencies at all levels have been watching closely for any sign of organised riots in pursuit of political objectives in Xinjiang'[64]. During the Deng phase, since the late seventies and early eighties, state policies towards religious groups like the Uyghur community were relaxed and a certain degree of religious freedom was introduced. This new 'freedom', however, has often been seen as illusory. The state is said to encourage religious activities only if religious groups speak the same language as the state, otherwise they are crushed. Other factors which have problematized the situation in Xinjiang include the Han migration from China proper. Since the fifties, the state has encouraged Han people to migrate from China proper to Xinjiang supposedly to 'develop' the region. This has complicated matters since many from the Uyghur side feel that this is a deliberate attempt by the state to undermine the ETIM and to dilute or weaken local Uyghur Islamic identity. 'The process of modernisation of urban areas in Xinjiang has been characterised by the steadily increasing number of the Han population'[65]. The economic benefits of the modernisation process tend to go to the Han Chinese, and this has left the Uyghur community feeling marginalised in their own land. Human rights abuses caused by the state are very common. There is an over representation of the Han Chinese in the major regional economic and political bodies, and Uyghur leaders are regularly undermined, and are subjected to periodic repression. The Chinese state has used the region as a nuclear testing ground and followed a policy of forceful cultural assimilation. Political oppression, sinification of Xinjiang, and economic exploitation of the region's resources to suit the needs of China proper have collectively complicated matters. 'Heavy restrictions were placed on freedom of speech in order to suppress the expression of alternative representations, labelled local nationalist and 'splittist' by the state'[66]. 'The trajectory of Chinese nationality policies is reflected in discrimination against minorities, the weakening of minority autonomous institutions in the 1950's, the attack on minority cultures and autonomy during the cultural revolution in the 1960's, and finally the modernisation agenda featuring the centralising and assimilating power of education and propaganda systems since the 1980 's' $[67]$.

Recently, I had the opportunity to meet up with a Uyghur Muslim man from Kashgar, where he had spent practically all of his life. I carried out a one hour interview with him, and asked him various questions about his life and about his personal experience in Xinjiang, Chinese intervention in the region and also about his own Uyghur identity. The interview was done on the 24th of July, 2012. Although this Uyghur gentleman had initially agreed to speak with me, at the time of the interview he expressed great nervousness and was actually quite unwilling to speak. However, he did provide me with some information, which I have found quite useful for purposes of this paper. 
Firstly, the very fact that he was not willing to share with me his views on Chinese state policies in Xinjiang, and that he refused to give me his views and personal opinions on state policy, itself gave me a picture of the political situation in Xinjiang. When asked about his views on state policy towards the separatist movement there, he refused to give me his personal views. Instead, he was more interested in telling me what he called, 'the Chinese version of events'. His fear of being found out by Chinese officials of what he told me, spoke a lot about the current situation there and hints at the oppressive nature of the political system, despite recent democratising tendencies[68]. He would insist on talking about 'the Chinese perspective or the Chinese version of events' rather than his own personal perspective[69]. For instance, when asked about what he felt about Chinese intervention in his part of China, he told me, 'it was meant to help Xinjiang and the Uyghur community with economic development and that it had nothing to do with making Xinjiang a colony.'

He mentioned that in his own life experience he had never experienced any problem with his Han Chinese colleagues. He mentioned that an 'insiders' perspective on the region would differ from an 'outsiders' perspective. Ultimately, he told me that he would like to maintain a neutral position on the Xinjiang question, and not go into the details of Xinjiang's colonisation by the Chinese. This was because the whole Xinjiang issue was very sensitive politically. He then went on to say that the local people of the province did not feel 'colonised' because they could not think that far or were not allowed to think that far due to severe state restrictions and local people actually felt quite scared to think of Xinjiang being China's colony[69]. He mentioned that only a small number of people who were involved in the separatist movement thought of the Xinjiang region as China's colony. He mentioned that the number of separatists were so small that they were almost invisible and hard to find[69]. He then went on to say that people ordinarily did not speak about such matters because they were politically sensitive issues.

He told me that one would only get to know about separatist movements only after the official media had reported on riots, otherwise one would not get to hear about separatist tendencies. In this connection, he mentioned about Rebiya Kadeer, and that she only became well known after the official media had spoken about her. He mentioned that she did not become famous because of her own efforts, and that she only rose to fame because of media reporting[69]. Local people, he said, may think of separatism and may think of a free East Turkestan [which is what Kadeer is currently fighting for] in their minds and hearts, but they do not openly talk about it. He mentioned that the diaspora has been very active in separatist politics because they have more freedom to express themselves, unlike the situation in China. In Xinjiang, itself, at the surface level, the situation seemed relaxed but the state worried too much about the issue of separatism, almost creating the problem, when sometimes it did not even exist. He mentioned that the Uyghur community in Xinjiang could not express themselves the way the Uyghur diaspora could express themselves and that Uyghur's all over the world were quite divided in their views with regard to Xinjiang and its political status. He went on to tell me that some Uyghur's wanted equal rights, some wanted more autonomy and some full independence, and also that some wanted to maintain what he called a 'middle path' meaning not full independence but not full subjugation under China[69].

I asked him about China carrying out its nuclear tests in Xinjiang and what he felt about that. To this he said that China had stopped nuclear tests in the eighties and nineties[69]. 
With regard to economic development, he spoke about people benefitting from the whole process of modernisation, but how much one actually benefitted differed from person to person. In other words, some groups benefitted more than others. To quote him, 'some ate the meat of the economic modernisation process, some just drank the soup of the economic modernisation process and some just got mere bones'[69]. He mentioned that both the Han Chinese and the Uyghur community benefitted from the modernisation process, but some benefitted more than others. To me, this seemed in conflict with the existing body of scholarly literature on Xinjiang and China's regional development, where scholars [both western and Uyghur's] have argued that the divide between the richer Han Chinese and the poorer Uyghur community is very pronounced and obvious. The Hans tend to be the richer out of the two communities and live in the more affluent urban centres and the Uyghur's tend to live in the poorer rural areas. He mentioned that the situation was not quite that black and white, and that there were poor Han Chinese people in the region as well as rich Uyghur people.

When asked about religion and religious affairs, he mentioned that more and more people were becoming religious and practising Islam privately, despite official restrictions[69]. He mentioned about Islamic leaders having to attend state run institutes in places like Urumqi for 'religious' training. He mentioned that there were no private madrasas in Xinjiang because it was impossible to run a private Islamic school. He also mentioned that if the state found out about privately run religious schools, they would be raided, which happened in both Korla and Khotan[69]. Privately run schools would be attacked by the state.

He maintained that the separatist movements in Xinjiang were 'sporadic'[69]and that they were not well organised or united and that even if there was an act of 'terrorism', it was probably an isolated incident. With regard to the ETIM, East Turkestan Islamic Movement, he believed that the leaders were based in Pakistan, if there were any leaders of the movement at all. No one really knows much about the ETIM, where it was/is based, who the leaders are, who the members are and how it was/is funded. 'Underground movements are not allowed to exist in China', he told me, and so they do not exist. Thus the background of the ETIM is shrouded in mystery. He maintained that similar groups and organisations come and go, but finally disappear because of state authority and state high handedness[69].

Finally, when asked about his own personal identity, he told me, he identified himself as just being Uyghur, and only Uyghur, and nothing else. To me, this in itself hinted at an element of distinctiveness, an identity separate from that of the Han Chinese and the rest of China. He could have identified himself as Chinese, but he chose not to. Instead, he mentioned that he was just Uyghur and nothing else[69].

Overall, I got the impression based on the information that he provided me with, that the Chinese political system was still very conservative and that religious groups found it hard to survive in such a conservative climate. The very fact that he was scared to talk to me about his own views in the first place [and rather talk to me about the state's view, or Chinese version of events, which I already knew] hints at this conservative political system and oppression. And although the state has been effective so far in suppressing religious groups and outward expressions of religion, it is doubtful as to how long this effectiveness will continue. As we know from history, the policy of might is right does not work for long and can often have the opposite effect. 
Let us now turn to our final case study, Tibet.

\section{XIZANG OR THE TIBETAN AUTONOMOUS REGION: BACKGROUND TO THE CONFLICT}

Geographically, the Tibetan Autonomous region lies to the south of China proper, closer to India. It is separated from India by the mighty Himalayan mountain range that lies in between the two countries. Although political borders are ill defined with regard to Tibet and its boundaries, 'its area has been estimated as 470, 000 square miles' [70]. Like Xinjiang, Tibet is also a deeply religious province, and hence has come under state pressure throughout China's contemporary history. Tibet has a strong Buddhist presence. Indian Buddhism fused with the local Bon tradition of Tibet and paved the way for Lamaism to come into existence in Tibet. The problem here is similar to the situation in Xinjiang, and again is a very complex ethno political issue. The conflict revolves around contested history and contested territory. When one looks at the Tibetan question one needs to pay close attention to the interactions that have taken place between religion, nationalism and so called 'democratic reform'[71].

The Tibet question has been one of the most burning issues in Asian politics. 'It has been heatedly debated and contested in many international forums. Today, world opinion is divided, cutting along, first of all, ideological lines and now, increasingly along lines for/against the PRC/People Republic of China'[72].There is no consensus when it comes to the national boundaries of Tibet. China proper has claimed that Tibet has always been a part of it, whereas the Tibetan side argues that it has always been independent. Tibet got incorporated into China proper during the time of the Manchu dynasty, which extended from 1644 till 1912. The Manchu state maintained a military garrison at Lhasa, as its representative, which has always been the political centre of Tibet. Between 1913, and 1950, local Tibetans ruled Tibet. 'Though the nature of Sino-Tibetan political relations before 1913 may be open to dispute, Tibet unquestionably controlled its own internal and external affairs during the period from 1913 to 1951 and repeatedly attempted to secure recognition and validation of its autonomy/independence'[73]. This was the time of Tibetan independence, and many Tibetan nationalists look back to these days. 1913, was the year when the thirteenth Dalai Lama, came back from exile, from India. In 1949, as we discussed earlier, the PRC/People's Republic of China came into existence, and in the early fifties, China proper invaded Tibet. Also, in 1951, the fourteenth Dalai Lama signed the very famous seventeen point agreement, which confirmed China's hold over the Tibetan region. Whilst the Chinese side recognises the seventeen point document as valid, the Tibetan side argues that the traditional religious leadership signed the paper under tremendous political pressure. Womack, a scholar on China writes, 'even though the conflict between China and the Dalai Lama regarding Tibetan autonomy is not one between sovereign states, it fits the pattern of asymmetric stalemate'[74].

After the Chinese invasion, the Tibetan government in exile was set up in north India. 'The Tibet Question dates from the Dalai Lama's exodus from Tibet to India after the failed uprising against Chinese authority in Lhasa in 1959'[75]. The Tibetan government in exile or the Central Tibetan Administration as it is also called sees the current situation in Tibet as an illegal occupation by the Chinese. They believe that the Dalai Lama is the true leader of Tibet. The Chinese side see themselves as liberators, liberating the Tibetan people from external and feudal influences. The Chinese believe that they brought modernity to Tibet. 'To the Chinese communists, Tibet was a part of China in need of liberation from both foreign imperialism and its own exploiting classes'[76]. 
Although much of the infrastructure in Tibet was designed mainly for the benefits of the Chinese military and the Han population from China proper that settled there, China did to some extent bring some element of modernity to Tibet and 'did drag parts of Tibet into the semi modern age and improve the standard of living of many Tibetans, but at a fearsome price which Tibetans were unwilling to pay'[77]. 'In its relations with its borderlands, the Chinese state, whether imperial, Republican or socialist, tended to view local denizens with a mixture of contempt and fear'[78]. The region was seen as backward and primitive by the Chinese, which needed development, and hence there have been flows of Han Chinese into the region for so called developmental reasons since the fifties till recently. The region is heavily militarised like the earlier case studies discussed in this paper, which has paved the way for human rights violations. Throughout the years of the Cultural Revolution, 1966-1976, the region came under tremendous political pressure and Buddhist monasteries were captured by the Chinese state, and put to secular use. Monks and nuns were forced to leave their religious temples and engage in hard labour. They were forced to participate in the modernisation process to move the economy ahead, and were forced to be involved in activities associated with agriculture and industry. From the eighties, however, a certain degree of religious and political freedom was introduced. 'Since 1980, Deng Xiao-ping has implemented a welfare policy in the Tibetan Autonomous Region to pacify the Tibetans. This policy has given the Tibetans unprecedented social welfare benefits better than that given to any other Chinese ethnic minority groups'[79]. Despite this, protests have continued, which has escalated levels of violence in the region. Monks and nuns have been regularly subjected to physical torture by the Chinese state since the invasion.

\section{NATIONALISM AND HUMAN RIGHTS IN XINJIANG, AND THE IMPACT OF EXTERNAL FORCES:}

\section{Nationalism in the Xinjiang Conflict:}

The conflict in Xinjiang is predominantly one of secessionist nationalism, which is anathema to the Chinese government. However, what has exacerbated the situation is the semi colonial/colonial approach taken by the Chinese state in dealing with the problem[80]. Uyghur nationalism in Xinjiang was inspired by Muslims in Central Asia. Wealthy merchants from places like Kashgar and Yili in Xinjiang travelled to places like Istanbul and on their return launched a movement to modernise Uyghur education. These new schools played a crucial role in strengthening the forces of separatism since they instilled Turkic and eventually nationalist Uyghur ideas in Uyghur children throughout the 1920's[81]. Those who were influenced by the Uyghur enlightenment were the ones who took part in the rebellions of the 1930's. The Uyghur community basically see themselves as a distinct nation, separate from the Chinese motherland. Although the Chinese Communist Party has been involved in a nation building process since the 50's, the Uyghur community have had their own counter strategies and their attempts to resist it. 'All parties involved in the contestation over Xinjiang have used history as a tool to serve political ends', argues well known American academic on Inner Asia, Gardner Bovingdon[82]. Chinese state actors have tried to manipulate and use the history-writing of the province to suit their own needs and to strengthen the states' hold over Xinjiang. The Chinese state gives the impression to the world that Xinjiang has been a part of China since ancient times and that it is an 'integral' part of China. This is quite similar to the way Hindu nationalists and state officials from India argue that Kashmir is an 'integral' part of India. In sharp contrast to the official accounts on Xinjiang, which claim that it has been a part of China for centuries, Uyghur nationalists and their accounts claim that they have lived there for six thousand years and that they founded many independent and powerful states in and near present day Xinjiang. The histories written by the Uyghur nationalist intellectuals are often as flawed and unreliable as the accounts of the Chinese officials where an 'us' pitted against 'them' approach is taken. This 'us-them' binary always over simplifies a very complicated story. Their writings often impart new vigour to the separatist forces of this province 
and have often galvanised the Uyghur community into action against the Chinese state. The Chinese state has responded by publicly burning these historical accounts in the public square and also by subjecting these intellectuals to torture and criticism. Despite this crackdown and public criticism, the central claims of Uyghur nationalist history have continued to circulate in Uyghur society, since members of the wider community play an active role in spreading these histories[82].

\section{Transnational Connections and the Xinjiang Conflict:}

The Chinese fear the forces of separatism in Xinjiang because of the massive border it shares with Central Asia, which it finds difficult to control. Also, the state fears the influences of political Islam from the south, where Xinjiang has a border with Afghanistan, Pakistan and India. Religions of foreign origin were seen to be undermining what state officials considered to be nationalist official state values. The connection between the separatist struggle in Xinjiang and the rise of the Taliban has often been raised within China, as well as outside the country but no one is certain about what real connections the two may have[83]. Beijing has claimed on a number of occasions that members of the Pakistani security forces were providing combat training to members of the Uyghur community in Afghanistan, who were then travelling back to Xinjiang to use this training there, to fight against the Chinese state and to subvert its policies. Chinese authorities have claimed that information and evidence has been available about this training from a group of sixteen Uighurs who had been arrested and interrogated whilst they were crossing the border back to Xinjiang[83]. It is also believed that a group of Uighurs have fought with Juma Namangani's movement, Islamic Movement of Uzbekistan, IMU. The Islamic Movement of Uzbekistan, it was said, was proving to be very attractive to Uyghur Muslims, who could now seek support for their own jihad. Former Chinese president, Jiang Zemin, has especially been worried about the Taliban and the Islamic movement of Uzbekistan providing Uighurs with doctrinal and military training and fomenting rebellion in Xinjiang[84]. In a very recent publication, entitled, 'The China-Pakistan Axis: Asia's New Geopolitics', Andrew Small writes, 'After the Taliban takeover, Afghanistan had become a base for ETIM/East Turkestan Islamic Movement and other Central Asian militants affiliated to them, such as the IMU/Islamic Movement of Uzbekistan, and the training camps that the Uyghur group established were in locations-including places in and around Kabul-that left no ambiguity about the fact that they operated with the consent of the country's new masters'[85].

It is often argued that because of the high handedness of the Chinese state and the repressive measures taken by state officials, there is so much that the Uyghur community within Xinjiang and China can do to make their secessionist movement a success/reality and gain independence from Chinese rule. In sharp contrast to their situation, the Uyghur diaspora who live in parts of North America and Europe, have played an active role in spreading awareness about the Uyghur problem amongst the international community and is trying to use the efforts of the international community [especially those of western governments] to put pressure on the Chinese establishment to free and let go of Xinjiang or what the members of the diaspora call, 'Uyghur-stan'. There are about five hundred Uighurs in Germany and most of them live in Munich[86]. Ninety five per cent of them are refugees or ex refugees and arrived in Europe in the eighties and nineties. 'There is no doubt that a large number Uyghur organisations outside Xinjiang have tried to shape the fate of this region and its peoples'[87]. Bovigndon argues that the diaspora has actively been involved in preparing histories and political material all around the world, and have tried to sustain the separatist movement. Uyghur organisations abroad have managed to smuggle in text books, beam in radio broadcasts, and send ideas across borders which challenge the story that the Chinese government is trying to impose on the region. Small Uyghur communities had formed in Germany, Sweden, the Low Countries, and have also been gathering in Canada, Australia and the United States[87,p146]. Many of these communities formed nationally bound Uyghur organisations such as the Belgium Uyghur Association, the Swedish Uyghur Committee, and the Australian and Canadian Uyghur Association. The Uyghur American Association though a national organisation, in recent times has become similar to transnational ones[88]. A similar transnational organisation is the world Uyghur congress which 
represents the collective interest of the Uyghur people in East Turkestan and abroad[89]. In this connection, it is worth mentioning about Rebiya Kadeer, who is the chairperson of the congress and fights for the 'self-determination, democracy and human rights of the Uighurs'[90]. Although Beijing has accused Kadeer of instigating violence within China, especially in Xinjiang, Kadeer has denied these accusations. These groups all aim at preserving Uyghur language and culture and they devote great energies in publicising the 'Uyghur Cause' and disseminating news affecting the Uyghur community. These bodies organise cultural events, aid refugees, publish news and produce films about Uyghur affairs[91].

'The changes in communications [internet, satellite television, videos etc.], inexpensive travel and telephone, greatly facilitate and thus increase direct contact between the diaspora and homeland providing immigrants with the possibility of playing an active role from some distance or through frequent travel to their former countries'[92]. These same facilities, the internet in particular, but also inexpensive travel provide the possibility for the creation of global communities of diasporas, holding transnational meetings and coordinating efforts to achieve a particular goal. Operating in their new roles with better opportunities and means, diasporas are often seen as more militant than those left behind in the mother country or home country, and are likely to contribute to the creation or prolongation of conflict[92].

\section{Human Rights Issues in Xinjiang:}

Xinjiang is a province which the Chinese have used to execute political prisoners. Amnesty International reports that Uyghur prisoners are often tortured in the most draconian ways which include sleep/food deprivation, exposure to extreme heat or cold, using trained dogs to attack prisoners, shocks, punishment with fists and instruments, inserting sticks or needles under finger nails or having finger nails pulled out entirely, administering injections causing the prisoner to become mentally unbalanced or to lose the ability to speak coherently. It is indeed shocking to see that these forms of torture still happen and happen in a country which has signed the UN Convention against Torture. Gross violations of human rights were perpetrated in the Xinjiang Uyghur Autonomous Region, the victims of which were mainly Uighurs[93]. Over the years, attempts made by the Uighurs to air their grievances and peacefully exercise their most fundamental rights have been met with repression[93]. Anyone in the Xinjiang Uyghur Autonomous Region found passing information from the region to the outside world about human rights abuses is at the risk of arbitrary detention and torture[94]. Amnesty International reported that Xinjiang was the only province, where individuals could be sentenced to death for political reasons. Amnesty International's research reveal several disturbing trends such as 'harassment by Chinese authorities of relatives of Uighurs who flee abroad, increasing attempts by the Chinese authorities to curtail the political and human rights activities of Uyghur activists abroad, and there was a growing fear amongst Uighurs living abroad, of being forcibly returned to China'[94]. Child labour is also a very common sight in the more remote and rural parts of the province and many young children are being excluded and deprived of school education[95].

\section{NATIONALISM AND HUMAN RIGHTS IN TIBET AND THE IMPACT OF EXTERNAL FORCES:}

\section{Nationalism in Tibet:}

Most scholars on Tibet have argued that this conflict is a case of nationalism and the fight for self-determination against Chinese rule by the Tibetans. The issue of Tibetan national identity inevitably involves the question whether or not Tibet was and is a nation. While Tibetans argue that they were and still are a nation, China denies this. Nationalism has become structurally embedded as the basis of the modern state everywhere. Tibetans have had to appropriate the language of nationalism to be able to fight against Chinese occupation and their versions of modernity. Tibetans strongly feel that they have a right to determine the course of action in Tibet, but this right has been 
denied to them by the Chinese government. The Dalai Lama led government in exile claims to speak for the rights of the Tibetan people[96]:

'The whole of Tibet should become a self-governing democratic political entity founded on law by agreement of the people for the common good and the protection of themselves and their environment, in association with the PRC".

This statement reflects a desire to project Tibet as one distinct political unit. In this question of nationalism, especially with regard to Tibetan nationalism, religion has played a crucial role and to be Tibetan is almost synonymous with being Buddhist. Tibetan Buddhist clergy men have led demonstrations in the eighties and this clearly shows that religious nationalism as a force has been quite strong in preventing the regions' full integration within China proper. The role played by the Tibetan Buddhist monks is quite similar to the role played by Burmese monks in their fight against the authoritarian state in recent times. The Chinese side of events, which clearly clash with the Tibetan version of events, argues that the Central government of China has continuously exercised sovereign authority over Tibet for more than seven hundred years, and that no country in the world has ever really given recognition to Tibet as an independent state[97]. The Chinese also do no not recognise the claim made by the Dalai Lama and his supporters that Tibet became independent between the 1911 revolution till 1949, when the People's Republic of China was founded, exercising full authority. This, they say is a fallacy, and the very fact that the fourteenth Dalai Lama needed the approval of the national government is sufficient proof that the region did not possess any independent power during that period. Therefore, the problem of 'Tibetan independence', which the Dalai Lama and his followers and anti-China forces advocate is nothing but a fiction of the imperial powers, who are committed to aggression against China in modern times[97]. These two conflicting views of Sino-Tibetan history thus stand as stumbling blocks to a negotiated settlement between Beijing and the Dalai Lama on the future status of Tibet. Thus, separatist forces with a strong nationalist agenda are still strong in Tibet.

\section{Human Rights Issues in the Region:}

Like Xinjiang, Tibet has been subjected to severe measures by the Chinese state and we have witnessed serious human rights abuses in the region in recent times, after the PRC came into existence. The Dalai Lama was very forthright on this issue in his July, 1996 speech, accusing the Chinese of 'cultural genocide' in Tibet[98]. The heavy presence of the People's Liberation Army in the region has made the situation much worse, curbing the rights and freedom of the people. 'China's objective in using the People's Liberation Army were straightforward-to gain control of Tibet'[99]. American human rights group, Asia Watch[100] states:

'The Chinese Communist party governs as an authoritarian one party state which sharply curbs freedom of expression, association and religion. It equates criticism of the party with subversion and rejects judicial independence and media freedom. The party also censors the internet and maintains highly repressive policies in the ethnic minority regions of Tibet and Xinjiang. Chinese citizens have become more and more rights conscious and increasingly challenge official abuses including land seizures, forced evictions and corruption. A small rights defence [weiquan] movement persists despite risks including surveillance, detention, arrest, enforced disappearance and torture. The Chinese governments growing global influence also poses increasing challenges to key international human rights norms and institutions.'

Amnesty International director, Kate Allen[101] said,

'Basic human rights are being routinely abused in Tibet. Reports from the region depict an increasing crackdown on free speech and right to protest.'

On the ninth of March, 2009, Amnesty International released a media briefing ahead of the fiftieth anniversary of the failed Tibetan uprising on March, 1959, which led the Dalai Lama fleeing to India. 
The report reveals escalating tension, repression and human rights abuse in the Tibetan Autonomous Region[101], which included the following:

Upto 1,400 of those detained in the March, 2008 protests still had not been released according to official figures.

Chinese lawyers had warned off taking up the cases of detained Tibetan protesters.

There were reports from detainees of beatings and refusal of food, water and medical treatment.

Tibetan monks and nuns, pop stars, artists, and writers had been detained in a crackdown.

Human rights abuses included arbitrary arrest, torture, restrictions on free speech and right to free assembly, and restrictions on their right to maintain their culture, language and religion.

Access to foreign journalists and UN human rights experts were denied or severely restricted.

The Human Rights section of the UN website[102] as recently as November, 2011, revealed that:

'A group of UN experts voiced grave concern over reports of severe human rights restrictions on Tibetan Buddhist monasteries in China's Sichuan province, which included intimidation, security raids and surveillance of the sites and religious activities. Heavy security measures have been reported in and around the area of the Tibetan Buddhist Kirti monastery, which houses some 2,500 monks and other monasteries in Aba County, an area of the south western Chinese province of Sichuan with many ethnic Tibetans'.

\section{Transnational Connections and the Tibetan Conflict:}

The discourse on Tibetan nationalism has had better luck with the diaspora and the Tibetan government in exile in Dharamsala, Himachal Pradesh, India. The Tibetan government in exile has made claims over central Tibet, Kham and Amdo, based on the existence of cultural and religious commonalities. Tibetan national identity both inside Tibet and outside Tibet is a product of constant negotiation and re-negotiation, and the transnational element is as significant as the indigenous element. 'The exiled Tibetans in India have led a vociferous campaign for a separation of Tibet from China and have been able to exploit China's dependency on foreign powers to promote their own interests. The United States, in particular, has been receptive to exiled Tibetan propaganda, which has also been mixed up with a highly loaded human rights crusade against China'[103]. The Tibetan government in exile, which is also called the Central Tibetan Administration, has as its aim to restore freedom for Tibetans[104]. Lobsang Sangay, the prime minister of the Tibetan government in exile remains committed to holding a dialogue with China on Tibet's future. Sangay said that his government was committed to a dialogue process with Beijing, 'to restore the Tibet issue on the basis of mutual benefit'.

\section{CONCLUDING REMARKS AND THE COMPARISON BETWEEN THE CASE STUDIES:}

From the above discussion, it is very clear that despite the differences in the nature of the political systems of the two countries, there are striking similarities when we look at the situation very closely in the contested borderland regions of India and China. To begin with, all four cases studies are and have been strongly associated with break-away groups. The main issue here has been the achievement of political independence or at least more autonomy from the mother country. Politically, the conflicts, by and large have thus revolved around the issue of sovereignty and self-determination. These conflict zones have been strongly related to secessionist movements, which tend to have a strong nationalist approach. They could also, all be classified as ethnic conflicts in one way or another, especially a conflict between ethnic minorities and ethnic majorities of the 
two countries. The background of the separatist groups tends to be shrouded in darkness and mystery. For most of these conflicts, no one really knows the whereabouts of the leaders who spearhead these separatist movements. Of course, it is also true, that in all four of the case studies, not all sections of the population want independence. As one of my interviewee's mentioned, some may want complete independence, but there are others who want more autonomy, and still others who just want their basic rights and a middle path. It could be argued that this fragmentation which exists within the insurgency applies to all four of the case studies. There is no unified vision or agenda. For instance, if we look at the Kashmir case, there is the more secular JKLF/Jammu and Kashmir Liberation Front and the more Islamist Hizb ul Mujahideen. Separatist leaders tend to quarrel amongst themselves, and factionalism exists to a large extent. This could also be the reason why the breakaway groups have not succeeded in separating from the mother country, and why some of these conflicts have gone on for so long. 'Upto the present day, Kashmir has not been decided to the satisfaction of all parties and remains one of the longest running disputes in the world'[105].

Both countries feel that there borderlands are crucial to their identity. The political elite in both countries have argued that borderland regions are an 'integral' part of India/China. And hence both countries have directly intervened in the conflicts in their respective borders. Both countries use their respective borders as buffer zones against external attacks. Both countries fear if one borderland region successfully secedes, then there will be a domino effect, and other disaffected minority groups in other borderland regions will follow suit.

All of the case studies suffer from geographical isolation, and are far removed from the country that they are fighting against. They are also far removed from the rest of the world. In all four of the case studies, the topography is highly mountainous, which has in some ways added to this isolation, and a lot of the political violence in the region originates from this feeling of isolation. The harsh geographical terrain has made communication networks quite difficult between the concerned region on the one hand, and the rest of the mother country on the other.

Economically, most of these peripheral regions are rich in natural resources like oil, natural gas, uranium, forest reserves, tea, coal etc. which the mother country has tried to exploit to suit the needs of the people living in the heartland region. Of course, in this connection, it is worth mentioning that China's contested borders are richer in natural resources and are more developed economically than India's contested borders, which are not only under developed, but in some cases absolutely impoverished e.g. Nagaland in the Indian northeast. Politically, the situation has been very oppressive in all four of the case studies for the past few decades. There are regular clashes between security personnel stationed in the region and the local people. Because all four of the case studies are heavily militarised, they are also the areas, where there have been the most human rights violations. The heavy presence of security personnel in the region has paved the way for all sorts of human rights abuses to take place.

In three of the above case studies, namely Xinjiang, Kashmir and the Indian northeast, as we have seen from the above discussion, cross border linkages have played a crucial role in the conflicts. Pakistan has helped insurgents in Kashmir, China and Myanmar has helped insurgents in the Indian northeast and Uyghur's have been spotted training in the AFPAK/Afghanistan-Pakistan region. 
Whilst India may have given protection to the Tibetan government in exile, this is not the same as actively supporting separatist groups.

In all four of the conflict zones, the conflict itself is quite sporadic. When one visits the region, one does not immediately get the impression that the region is a conflict zone[106]. One needs to stay longer to witness the outbursts of violence. In all four case studies we see the state following a policy of high-handedness e.g. the Armed Forces Special Powers Act in Indian Kashmir and the Indian Northeast. There are different but similar laws in the Chinese context. Human rights abuses in all four regions is common. With regard to violence meted out from the side of the state, it is also worth mentioning that India, being a democracy is constrained by constitutional liberalism, and the security personnel will go so far. In other words, the Indian state's violence is calibrated or checked. In the Chinese case it could be argued that there is a freer hand in the violence directed at Xinjiang and Tibet from Beijing, with it being an authoritarian state.

Another area of similarity is that when the local people of these regions travel to the heartland regions of the country, that is, to India proper or to China proper, they are often subjected to racial discrimination. In other words, they are often viewed as the Indian 'other', or the Chinese 'other'. That said, it must be noted that in the Indian case, there is also an element of positive discrimination directed at minority groups coming from the borderlands. India being a democracy has a duty to secure the rights of its minority citizens. Thus, we see seats being reserved for ethnic minorities in the areas of education and employment. Terms and conditions for ethnic minorities in the Indian context is often relaxed, especially when it comes to education and jobs.

Apart from self-determination, and the attempt to carve out an independent state, another major burning political issue that has affected most of the case studies other than Kashmir is the issue of migration. Migration is very central to the conflicts in the Indian northeast, Chinese Xinjiang, and Tibet, although there are differences between the Indian context and the Chinese context. In the Chinese context, the state has deliberately followed an official policy, by which Han Chinese are transferred from the Chinese mainland to these peripheral provinces to supposedly 'develop' the region. These waves of Han migration have gone a long way in exacerbating the problem since many of the locals think that the Chinese state is doing this on purpose to weaken the regional identity and to weaken the centrifugal forces/breakaway groups in the region. With regard to the borderland regions of India, India has not followed a similar policy like the Chinese yet, by which people from the Indian heartland or India proper are moved to the peripheral parts of the country to curb the separatist tendencies. It is indeed true that migration has been a major cause of concern in the Indian northeast, but this is primarily from Bangladesh which has a massive border with the northeast Indian states, and this border cannot often be controlled well. The tribal groups in the Indian north east have complained about these continuous waves of migration from Bangladesh, but not in the same way the Tibetans and Uyghur's have. Some of the tribal groups do believe that their mongoloid ethos is being weakened due to Bangladeshi infiltration, but the accusation hurled at New Delhi is that Delhi has not shown much interest to deal with the issue, and has not done much to stop the migration from happening. Most of the Bangladeshi migrants are poor economic migrants, unlike the Han, who tend to be rich and skilled professionals. In the Chinese case, the state has followed a deliberate policy to sinify or hanify both Xinjiang and Tibet. China has tried to make both regions more Chinese. India has not followed any such policy yet to Indianise Kashmir or for that matter the Indian northeast. On the contrary, according to some Hindu nationalists, far from 
Indian-ising the borders, the Bangladeshi migration is undermining India's Hindu ethos, since most Bangladeshi's are Muslim. India has not followed the strong integrationist policies of cultural assimilation with regard to its borderland regions, the way China has. By and large, India has tried to accommodate cultural difference within its national framework, being a liberal democracy. Despite the differences in the two countries, the local people of three of our case studies, Xinjiang, Tibet and the Indian northeast have complained of culture genocide or cultural erosion and that local/regional identity is being increasingly undermined either through Han migration from China proper or by Bengali migration from Bangladesh.

The Kashmir case study is similar to that of Chinese Xinjiang in that they are both predominantly Muslim regions. Since $9 / 11$, state officials have often viewed both Kashmir and Xinjiang as hotbeds of Islamic radicalism, which is supposedly adversely impacting on regional Asian security. For instance, 'in early 2002 Indian intelligence informed the CIA that bin Laden was hiding in Kashmir'[107]. Also, when we look at China, 'the central government's top concern in Xinjiang, and in that matter, in other border provinces, was and still is security'[108]. Tibet in some ways is culturally similar to the Indian northeast where there is also a strong Buddhist presence, although the Indian northeast is more culturally diverse. Other major religions in the Indian north east include Hinduism and Christianity. Again to break this down a bit further, within China, Xinjiang is probably more complex and culturally diverse than Tibet. This is because, although the Uyghur's have a dominant position in Xinjiang, the region is also home to various other ethnic groups from Central Asia like the Kazakhs, Uzbeks, Kyrgyz and Tajiks. Similarly, the Indian northeast is highly divided along racial, religious, ethnic and linguistic lines. Whilst Kashmir and Tibet are also complex regions, it could be argued that they are not as complex or as culturally diverse as the other two case studies.

Although most of these conflict zones have both an external dimension and an internal dimension, it could be argued that the internal dimension of the conflict (which is linked to repressive state policies in the region) has flared up in recent decades, and the external dimension or the role played by external actors has now somewhat mellowed down. In the past, China has been actively involved in the Indian northeast, and Pakistan has been involved in Kashmir. Now the direct involvement of external powers seems to have mellowed down. With the improvement of Sino-Indian economic relations, and with the concept of 'Chindia' (two distinct but integrated economies) gaining in strength, China is not likely to meddle in India's northeast to destabilise India. India has not been involved in China's conflict zones other than offering shelter to the Dalai Lama, which of course did not go down well with the Chinese establishment.

In the final analysis, it could be argued that despite some of the differences between the case studies from India, and those from China, there are striking similarities which exist, which seem to bring all the four conflict zones together. Some of these areas of similarity include poverty, economic deprivation and unemployment amongst the locals, poor governance, strong forces of ethnic nationalism, administrative failure, human rights abuses, draconian laws that these areas are subjected to, political oppression, and political corruption. 


\section{References:}

1. Frankfort-Nachmias, C., and Nachmias, D., (1992) Research Methods in the Social Sciences, New York: St.Martins Press.

2. Webb, M.J., (2012) 'Escaping History or Merely Re-writing it? The Significance of Kashmir's Accession to its Political Future', Contemporary South Asia, 20(4), 471-485.

3. Mukherjee, K., (2014) 'The Kashmir Conflict in South Asia: Voices From Srinagar', Defence and Security Analysis, 30(1), 44-54.

4. Ganguly, S., (2001) Conflict Un-ending: India Pakistan Tensions Since 1947, New York: Columbia University Press.

5. Yasmeen, S.,(2003) 'Pakistan's Kashmir Policy: Voices of Moderation?' Contemporary South Asia, 12(2) 187-202.

6. Lieven, A., (2011) Pakistan: A Hard Country, London: Penguin Books.

7. Singh, P., (2010)Kohima to Kashmir: On the Terrorist Trail, New Delhi, Rupa and Co.

8. Schofield, V., (2008) 'Kashmiri Separatism and Pakistan in the Current Global Environment', Contemporary South Asia, 16(1) 83-92.

9. Hiro, D., (2011) Jihad on Two Fronts: South Asia's Unfolding Drama, New Delhi: Harper Collins Publishers.

10. Snedden, C., (2013) Kashmir: The Unwritten History, New Delhi: Harper Collins.

11. Bajpai, K., (2002) Roots of Terrorism, New Delhi: Penguin Books.

12. Razdan, T.N., (2012) 'Appeasement Policy and the Kashmir Crisis', in R.Sinha(ed) Secular India: Politics of Minoritysm, New Delhi: Vitasta.

13. Sengupta, N., (2011) Land of Two Rivers: A History of Bengal from the Mahabharata to Mujib, New Delhi: Penguin.

14. Bose, S., and Jalal, A., (1998) Modern South Asia: History, Culture and Political Economy, New Delhi: Oxford University Press.

15. Rashid, A., (2009) Descent into Chaos: Pakistan, Afghanistan and the Threat to Global Security, London/New York: Penguin.

16. Nanavatty, R.K., (2013) Internal Armed Conflict in India: Forging a Joint Civil-Military Approach, New Delhi: Pentagon Press.

17. Prakash, S.,(2000) 'The Political Economy of Kashmir since 1947', Contemporary South Asia, 9(3) 315-337.

18. Joseph, T., (2000)'Kashmir, Human Rights and the Indian Press', Contemporary South Asia, 9(1) 41-55.

19. Interview carried out in April, 2014. Details of the interviewee have been withheld.

20. Sabhlok, S.G., (2009) 'Civil Society and Development: Between Peace and Insurgency in the Northeast', South Asia: Journal of South Asian Studies, 32(3)501-517.

21. Singh, M.A.,(2008) 'Ethnic Diversity, Autonomy and Territoriality in Northeast India: A Case of Tribal Autonomy in Assam', Strategic Analysis, 32(6)1101-1114

22. Hussain, W.,(2007) 'Ethno-nationalism and the Politics of Terror in India's Northeast', South Asia: Journal of South Asian Studies, 30(1)93-110.

23. Haokip, T., (2012) 'Recent Trends in Regional Integration and the Indian Experience', International Area Studies Review, 15(4)377-392.

24. Kipgen, N., (2013) 'Politics of Ethnic Conflict in Manipur', South Asia Research, 33(1)21-38. 
25. Haokip, T., (2013) 'The Kuki-Naga Conflict in the Light of Recent Publications', South Asia Research, 33(1)77-87.

26. Dutta, S., (2000) 'Security on India's North-east: External Linkages', Strategic Analysis, 24(8)1495-1516.

27. Haokip, T., (2012) 'Political Integration of North-eastern India: A Historical Analysis', Strategic Analysis, 36(2)304-314.

28. Baruah, S., (2009) 'Separatist Militants and Contentious Politics of Assam, India: The Limits of Counter Insurgency', Asian Survey, 49(6)951-974.

29. Mc-Duie-Ra, D., (2009) 'Vision 2020 or Revision 1958: the Contradictory Politics of Counter Insurgency in India's Regional Engagement', Contemporary South Asia, 17(3)313-330.

30. Participant Observation. Field Research Trip to North East India, 2012/2013.

31. Farelly, N., (2009) 'AK47/M16 Rifle-Rs.15,000 each: what price peace on the Indo Burmese Frontier?' Contemporary South Asia, 17(3)283-297.

32. Mukherjee, K., (2014) 'The Conflict in the Indian North East', Defence Studies, 14(2)111-133.

33. Singh, G., (2007), 'A Decade of Ceasefire in Nagaland', Strategic Analysis, 31(5)815-832.

34. Goswami, N., (2010) 'The Naga Intra Community Dialogue: Preventing and Managing Violent and Ethnic Conflict', Global Change, Peace and Security, 22(1)93-120.

35. Participant Observation/Research Trip, 2013/2014.

36. Singh, G., (2008) 'In Search of Peace in Manipur: Lessons from Nagaland', Strategic Analysis, 32(6)1115-1129.

37. Thokchom, K., (2014) 'Always Present, Remembered Now', The Telegraph, Calcutta.

38. Bora, P., (2014) 'Seasons in the Sun', The Telegraph, Calcutta.

39. Dutta, S., (2000) 'North East Turmoil: Vital Detriments', Strategic Analysis, 23(12)2123-2133.

40. Dutts, S., (2001) 'What Ails the North East: An Enquiry into the Economic Factors', Strategic Analysis, 25(1) 73-87.

41. Rao, K., (2009) 'Insurgency in the North East: Ills and Remedies', Strategic Analysis, 33(2)208213.

42. Mc-Duie-Ra, D., (2009) 'Fifty Year Disturbance: the Armed Forces Special Powers Act and Exceptionalism in a South Asian Periphery', Contemporary South Asia, 17(3)255-270.

43. Kikon, D., (2009) 'The Predicament of Justice: 50 years of Armed Forces Special Powers Act in India', Contemporary South Asia, 17(3)271-282.

44. For further discussion, refer to Mukherjee, K., (2014) 'Comparing India's Disputed Borderlands: Kashmir and the Northeast', Jadavpur Journal of International Relations, 18(1)31-62.

45. Thomas, R.J.C., (1996) Democracy, Security and Development in India, New York: St. Martin's Press.

46. Puri, B., (1993) Kashmir: Towards Insurgency, New Delhi: Orient Longman.

47. www.hrw.org/news/2010/09/17 (Accessed, 18.082012)

48. Bajpai, K., (2002) Roots of Terrorism, New Delhi: Penguin.

49. Kapur, A., and Wilson, A.J., (1996) Foreign Policies of India and her Neighbours, New York: St. Martin's Press.

50. Thomas, R.G.C., (1996) Democracy, Security and Development in India, New York: St.Martin's Press.

51. Talbot, I., and Singh, G., (1999) eds, Region and Partition: Bengal, Punjab and the Partition of the Subcontinent, Oxford: Oxford University Press. 
52. www.womensurvivorsnetwork.org/article (Accessed, 21.08.2012)

53. www.amnesty.org.uk (Accessed, 21.08.2012)

54. www.cafi-online.org/about-us.php (Accessed, 21.08.2012)

55. Goswami, N., (2012)'Making Sense of Insurgencies in North Eastern India: An Overview', in S.Dutt and A.Bansal, eds, South Asian Security: $21^{\text {st }}$ Century Discourses, London/New York: Routledge.

56. Bajpai, K., (2002) Roots of Terrorism, New Delhi: Penguin.

57. Dillon, M., (2004) Xinjiang: China's Muslim Far Northwest, London: Routledge.

58. Bovingdon, G., (2010) The Uighur's: Strangers in their own land, New York: Columbia University Press.

59. McMillan, A., (2009) 'Xinjiang and Central Asia: Interdependency, Not Integration', in C.Mackerras and M.Clarke, eds, China, Xinjiang and Central Asia: History, Transition and Cross Border Interaction into the $21^{\text {st }}$ Century, London/New York: Routledge.

60. Mukherjee, K., (2010) 'The Uyghur Question in Contemporary China', Strategic Analysis, 34(3)420-435.

61. Mukherjee, K., (2015) 'Comparing China's Contested Borders: Xinjiang and Tibet', Millenial Asia: International Journal of Asian Studies, 6(1) Forthcoming.

62. Rudelson, J.J., (1997) Oasis Identities, New York: Columbia University Press.

63. Hao, Y., and Liu, W., (2012) 'Xinjiang: Increasing Pain in the heart of China's Borderland', Journal of Contemporary China, 21(74)205-225.

64. Chen, N., (2012) 'Beijing's Political Crisis Communication: An Analysis of Chinese Government Communication in the 2009 Xinjiang Riot', Journal of Contemporary China, 21(75)461-479

65. Rahman, A.,(2005) Sinicization Beyond the Great Wall: China's Xinjiang Uyghur Autonomous Region, Leicester: Matador.

66. Finley, J.S., (2007) 'Chinese Oppression in Xinjiang, Middle Eastern Conflicts and Global Islamic Solidarities Among the Uighur's', Journal of Contemporary China, 16(53)627-654.

67. Bulag, U.E., (2000) 'Ethnic Resistance with Socialist Characteristics', in E.Perry and M.Selden, eds, Chinese Society: Change, Conflict and Resistance, Abingdon: Routledge.

68. Howell, J., (2004) Governance in China, Lanham: Rowman and Littlefield Publishers.

69. Interview carried out by the author in July, 2012. Identity of the interviewee has been withheld. Interviewee does not wish to reveal his identity.

70. Carrasco, P., (1959) Land and Polity in Tibet, Seattle: University of Washington Press.

71. Mukherjee, K., (2010) 'China-Tibet Relations from 1950 until 2008: the interaction between Religion, Nationalism and Reform', Korean Journal of Defence Analysis, 22(4)467-483.

72. Norbu, D., (2001) China's Tibet Policy, Surrey: Richmond Curzon.

73. Goldstein, M.C., (1989) A History of Modern Tibet, 1913-1951: The Demise of the Lamaist State, Berkeley: University of California Press.

74. Womack, B., (2007) 'Resolving Asymmetric Stalemate: the Case of the Tibetan Question', Journal of Contemporary China, 16(52)443-460.

75. Sautman, B., (2002) 'Resolving the Tibet Question: Problems and Prospects', Journal of Contemporary China, 11(30)77-107.

76. Smith,W., (1996) Tibetan Nation: A History of Tibetan Nationalism and Sino-Tibetan Relations, Boulder, Colorado: Westview Press. 
77. Margolis, E.S., (2001) War on top of the world: The struggle for Afghanistan, Kashmir and Tibet, London: Routledge.

78. Lary, D., (2007) eds, The Chinese State at the Borders, Vancouver/Toronto:UBC Press.

79. Mingxu, X., (1998) 'Complete Autonomy: The best approach to peaceful resolution of the Tibet problem', Journal of Contemporary China, 7(18)369-378.

80. Sheehan, J., 'China's Dangerous Dilemma in Xinjiang', www.nottingham.ac.uk/cpi/publications (Accessed, 03.08.2012)

81. Mukherjee, K., (2010) 'The Uyghur Question in Contemporary China', Strategic Analysis, 34(3)420-435.

82. Bovingdon, G., (2010) The Uyghur's: Strangers in their own land, New York: Columbia University Press.

83. Dillon, M., (2004) Xinjiang: China's Muslim Far Northwest, London: Routledge.

84. Rashid, A., (2002) Jihad: The Rise of Militant Islam in Central Asia, New Haven: Yale University Press.

85. Small, A., (2015) The China Pakistan Axis: Asia's New Geopolitics, New York: Oxford University Press.

86. Rahman, A., (2005) Sinicization Beyond the Great Wall: China's Xinjiang Uyghur Autonomous Region,(Leicester:Matador).

87. Bovingdon, G., (2010) The Uyghur's: Strangers in their own land, New York: Columbia University Press.

88. http://uyghuramerican.org (Accessed, 03.08.2012)

89. www.uyghurcongress.org (Accessed, 03.08.2012)

90. http://news.bbc.co.uk/1/hi/4357607.stm (Accessed, 03.08.2012)

91. Bovingdon, G., (2010) The Uyghur's: Strangers in their own land, New York: Columbia University Press.

92. Golan,G., and Gal, A., (2009) 'Globalisation and the Transformation of Conflict', in B.Dayton and L.Kriesberg, eds, Conflict Transformation and Peacebuilding, London/New York: Routledge.

93. 'People's Republic of China: Gross Violations of Human Rights in the Xinjiang Uyghur Autonomous Region', Amnesty International Report, 1999.

94. People's Republic of China: Uyghur's Fleeing Persecution as China wages its War on Terror, Amnesty International Report, 2004.

95. Rahman, A., (2005) Sinicisation Beyond the Great Wall: China's Xinjiang Uyghur Autonomous Region, Leicester: Matador.

96. His Holiness, the Dalai Lama, (1988), (1973)Westport: Conn Hyperion Press.

97. www.china.org.cn/e-white/tibet (Accessed, 10.08.2012)

98. Mackerras, C., (2004) 'China's Minorities and National Integration', in L.H.Liew and S.Wang, eds, Nationalism, Democracy and National Integration in China, London: Routledge.

99. Segal, G., (1985) Defending China, Oxford: Oxford University Press.

100. www.hrw.org/asia/china (Accessed 10.08.2012)

101. www.amnesty.org.uk (Accessed, 10.08.2012)

102. www.un.org/apps/news (Accessed, 10.08.2012)

103. Christiansen, F., and Rai, S., (1996) Chinese Politics and Society, Michigan: Prentice Hall.

104. $\quad$ http://tibet.net (Accessed, 10.08.2012) 
105. Khan, Y., (2007) The Great Partition: The Making of India and Pakistan, New Delhi: Penguin Books.

106. Field Research Trips to Asia, 2012, 2013, 2014, and 2015.

107. Ahmed, A., (2013) The Thistle and the Drone: How America's War on Terror Became a Global War on Tribal Islam, New Delhi: Harper Collins Publishers.

108. Yee, H.S., (2003) 'Ethnic Relations in Xinjiang: A Survey of Uyghur-Han Relations in Urumqi', Journal of Contemporary China, 12(36)431-452. 